Buana Sains Vol 18 No 1: 47 - 50, 2018

\title{
FAKTOR - FAKTOR YANG MEMPENGARUHI PERMINTAAN DAGING BROILER DI KOTA MALANG
}

\author{
Ariani Trisna Murti dan Sri Andika Putri \\ Program Studi Peternakan, Fakultas Pertanian, Universitas Tribhuwana Tunggadewi
}

\begin{abstract}
The research was conducted on a number of consumers who bought broiler chicken and not sold again. The number of respondents in each market amounted to 100 respondents incidental sampling. Research location was chosen with consideration because the big market is in the middle of the city, while for dinoyo market because of its location on subdistrict and reside in the residential area. The data collected are primary and secondary data. The type of this research is quantitative descriptive, that is research which describes or describe characteristic from a state or object of research done through data collecting, data analysis and interpretation result of its analysis. The research method used survey method. Data processing from the results of research conducted using Cobb-Douglas function using SPSS version 16.0. Based on the results of research conducted on broiler consumers in Malang City can be concluded that the factors that affect the level of demand for broiler meat in the city of Malang is the price of the goods themselves (broiler meat prices), price of chicken meat, beef prices, cooking oil prices, incomes per capita, education and consumer tastes.
\end{abstract}

Keywords: Factor; influence; price; demand; broiler

\section{Pendahuluan}

Populasi penduduk yang mengalami peningkatan menyebabkan kesadaran masyarakat akan perbaikan taraf hidup. Peningkatan permintaan terhadap pemenuhan kebutuhan pangan baik protein nabati maupun protein hewani merupakan salah satu bentuk kesadaran dari masyarakat. Pembangunan subsektor peternakan telah melakukan berbagai upaya yang mempunyai tujuan utama yaitu memenuhi kebutuhan protein hewani dari kebutuhan pangan. Kualitas ternak perlu ditingkatkan dan dikembangkan untuk meningkatkan produktivitas ternak.

Broiler merupakan salah satu sumber pangan protein hewani yang dagingnya menjadi konsumsi primadona, dan sebagai salah satu alternatif pengganti daging sapi. Alasan daging broiler menjadi primadona adalah waktu panen yang relatif cepat berkisar pada 35 hari sampai 40 hari, bahkan saat ini broiler dapat dipanen sesuai dengan permintaan pembeli. Produksi daging broiler secara nasional menunjukkan bahwa produksi daging masih banyak mengalami angka yang berfluktuasi. Tahun 2011 produksi sebesar 1.337.911 ton, tahun 2012 sebesar 1.400 .470 ton, tahun 2013 sebesar 1.497 .873 ton, tahun 2014 1.544.379 ton dan tahun 2015 produksi ayam broiler adalah sebesar 1.627.106 ton (Direktorat Jenderal Peternakan, 2016).

Permintaan masyarakat terhadap daging broiler dipengaruhi oleh berbagai 
A. T. Murti dan S.A.Putri/ Buana Sains Vol 18 No $1: 47-50$

faktor penting. Perubahan jumlah permintaan daging broiler tidak hanya dipengaruhi oleh harga daging broiler itu sendiri tetapi faktor harga barang-barang kebutuhan pokok pelengkap lain seperti ikan, telur, daging sapi, beras, minyak goreng, jumlah anggota keluarga, usia, jenis kelamin, pendidikan, selera masyarakat, dan tingkat pendapatan konsumen yang mempengaruhi daya beli. Perilaku dan keputusan pembelian konsumen besar dipengaruhi secara bersama-sama oleh faktor ekonomi dan non ekonomi.

Kota Malang merupakan kota terbesar kedua setelah Surabaya yang terletak di Provinsi Jawa Timur, serta menjadi salah satu kota terbesar di Indonesia menurut jumlah penduduk. Banyaknya fasilitas pendidikan yang memadai menjadikannya sangat cocok untuk belajar atau menempuh pendidikan. Sarana transportasi yang memadai dan biaya hidup yang relatif terjangkau menjadi daya tarik tersendiri. Tidak heran bila kebutuhan konsumsi di Kota Malang relatif tinggi karena adanya penambahan pendatang yang menjadi pelajar selain dari penduduk asli Kota Malang. Potensi konsumsi daging broiler yang tinggi, tidak diimbangi dengan produksi daging broiler yang tinggi, sehingga kebutuhan penduduk kota Malang akan daging broiler harus dipenuhi dari daerah luar kota malang, untuk itu penelitian tentang permintaan daging broiler di Malang perlu dilakukan.

\section{Metode Penelitian}

Penelitian dilaksanakan mulai bulan Mei sampai dengan Agustus 2017. Lokasi pengambilan data pada penjual daging broiler dilakukan di jalan Letjen Sutoyo, jalan Sudanco Supriyadi, jalan Danau Toba dan jalan Tlogomas dengan pertimbangan bahwa lokasi tersebut telah mewakili pusat 4 arah mata angin Kota Malang.

Metode penelitian yang digunakan adalah metode survey. Data yang diperoleh untuk kepentingan penelitian adalah data primer dan sekunder. Data primer diperoleh dengan cara memberikan daftar pertanyaan di dalam kuisioner yang telah dipersiapkan pada masing-masing responden. Data sekunder diperoleh dari intansi - instansi yang terkait dengan penelitian seperti Dinas Pertanian, Badan Pusat Statistik (BPS), beserta literature yang relevan sebagai pendukung dari hasil penelitian.

Pengambilan sampel dilakukan secara insidental sampling. Penelitian ini menggunakan sampel dengan jumlah 100 orang dengan pisah menjadi 6 lokasi penelitian sehingga masing-masing lokasi penelitian adalah 16 sampel kecuali pasar besar Malang yang sampelnya 20 dengan pertimbangan lokasinya yang besar. Roscoe dalam Sugiyono (2011) menjelaskan bila dalam penelitian akan melakukan analisis dengan multivariate (korelasi atau regresi ganda), maka jumlah anggota sampel minimal 10 kali dari jumlah variabel yang di teliti.

Analisa data yang dipergunakan dalam penelitian menggunakan fungsi Cobb-Douglas. Fungsi Cobb-Douglas adalah suatu fungsi atau persamaan yang melibatkan dua atau lebih variabel, di mana variabel yang satu disebut variabel dependent, yang dijelaskan $(\mathrm{Y})$ dan yang lain disebut variabel independent, yang menjelaskan (X). Penyelesaian hubungan antara $\mathrm{Y}$ dan $\mathrm{X}$ adalah dengan menggunakan cara regresi dimana variasi dari Y akan dipengaruhi oleh variasi X. Fungsi Cobb-Douglas dapat dituliskan seperti persamaan :

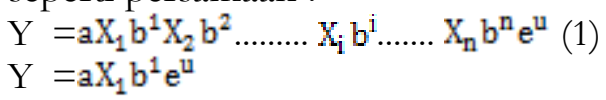

Bila fungsi Cobb-Douglas tersebut dinyatakan oleh hubungan $\mathrm{Y}$ dan $\mathrm{X}$, maka : 
A. T. Murti dan S.A.Putri/ Buana Sains Vol 18 No 1 : 47-50.

$\mathrm{Y}=\mathrm{f}\left(\mathrm{X}_{1}, \mathrm{X}_{2}, \mathrm{X}_{3}, \mathrm{X}_{4}, \mathrm{X}_{5}\right.$

dimana :

$\mathrm{Y}=$ permintaan daging broiler

$\mathrm{X}_{1}=$ harga daging broiler $(\mathrm{Rp} / \mathrm{kg})$

$\mathrm{X}_{2}=$ harga daging ayam kampung $(\mathrm{Rp} / \mathrm{kg})$

$\mathrm{X}_{3}=$ harga daging sapi $(\mathrm{Rp} / \mathrm{kg})$

$\mathrm{X}_{4}=$ harga telur ayam ras $(\mathrm{Rp} / \mathrm{kg})$

$\mathrm{X}_{5}=$ harga beras $(\mathrm{Rp} / \mathrm{kg})$

$\mathrm{X}_{6}=$ harga minyak goreng $(\mathrm{Rp} / \mathrm{kg})$

$\mathrm{X}_{7}=$ pendapatan rumah tangga $(\mathrm{Rp})$

$\mathrm{X}_{\mathrm{8}}=$ jumlah anggota keluarga (orang)

$\mathrm{X}_{9}=$ usia

$\mathrm{X}_{10}=$ jenis kelamin

$\mathrm{X}_{11}=$ pendidikan

$\mathrm{X}_{12}=$ selera

$\mathrm{a}, \mathrm{b}=$ besaran yang akan diduga

$\mu \quad=$ kesalahan (disturbance term)

$\mathrm{e} \quad=$ logaritma natural, $\mathrm{e}=2,718$

\section{Hasil dan Pembahasan}

Variabel-variabel pada penelitian yang memberikan pengaruh signifikan terhadap permintaan daging broiler kota Malang dapat diketahui menggunakan analisis regresi Cobb Douglas. Proses pengolahan data dengan menggunakan pendekatan analisis regresi linier berganda, tapi sebelumnya dilakukan transformasi Logaritma Natural (Ln) pada data, selain itu juga dilakukan beberapa tahapan untuk mencari pengaruh dari variabel independen terhadap dependen. Soekartawi (2002) menjelaskan bahwa fungsi produksi Cobb Douglas adalah suatu fungsi atau persamaan yang melibatkan dua atau lebih variabel, dimana variabel satu disebut variable dependent (Y) yang djelaskan, dan yang lain merupakan variable independent $(\mathrm{X})$. Alasan praktis Cobb Douglas sering dipergunaka adalah bentuk fungsi yang sederhana, fungsi produksi dapat menggambarkan keadaan skala hasil, koefisien-koefisien fungsi produksinya menggambarkan elastisitas produksi dari setiap input untuk dikaji, dan koefisien intersep dari fungsi produksi merupakan indeks efisiensi produksi yang secara langsung menggambarkan efisiensi penggunaan input dalam menghasilkan output dari sistem produksi yang dikaji. Berdasarkan hasil pengolahan data dengan menggunakan software SPSS 15 diperoleh hasil seperti pada Tabel berikut :

Tabel 1. Hasil Analisis Regresi Fungsi Permintaan Daging Broiler Di Kota Malang

\begin{tabular}{|l|l|}
\hline Variabel Pengamatan & Nilai $\beta$ Koefisien \\
\hline Konstanta & 1374,168 \\
\hline Harga daging broiler (x1) & $-0,264^{* * *}$ elastisitas harga \\
\hline Harga daging ayam kampung (x2) & $-0,315^{* * *}$ \\
\hline Harga daging sapi (x3) & $-0,299^{* * *}$ \\
\hline Harga Telur ayam ras (x4) & $-0,116$ \\
\hline Harga beras (x5) & $-0,021$ \\
\hline Harga minyak goreng (x6) & $-0,222^{* *}$ elastisitas silang \\
\hline Pendapatan (x7) & $0,141^{*}$ elastisitas pendapatan \\
\hline Banyak anggota keluarga (x8) & 0,072 \\
\hline Usia (x9) & $-0,096$ \\
\hline Jenis kelamin (x10) & $-0,015$ \\
\hline Pendidikan (x11) & $-0,287^{* * *}$ \\
\hline Selera (x12) & $0,479^{* * *}$ \\
\hline R-square & 0,690 \\
R $_{\text {adj }}$ & 0,647 \\
\hline F-hitung & 16,101 \\
\hline
\end{tabular}

(Data primer yang diolah, 2017) 
Berdasarkan hasil analisis satatistik dengan logaritma natural diketahui bahwa faktor yang mempengaruhi tingkat permintaan daging broiler di kota Malang adalah harga barang itu sendiri (harga daging broiler), harga daging ayam kampung, harga daging sapi, harga minyak goreng, pendapatan per kapita, pendidikan dan selera konsumen. Faktor tersebut berpengaruh terhadap permintaan sebesar 69\% dan sisanya sebesar 31\% dipengaruhi oleh variabel lain di luar penelitian.Persamaan regresi hasil transformasi data dalam bentuk logaritma natural (Ln) sebagai salah satu bentuk pengamatan elastisitas dari faktor produksi adalah sebagai berikut :

$\mathrm{Y}=1374,168-0,264 \mathrm{X} 1-0,315 \mathrm{X} 2$ $-0,299 \mathrm{X} 3-0,222 \mathrm{X} 6+0,141 \mathrm{X} 7-$ $0,287 \mathrm{X} 11+0,479 \mathrm{X} 12$

Keterangan:

$\mathrm{Y}=$ Jumlah permintaan

$\mathrm{X} 1=$ harga daging broiler $(\mathrm{Rp} / \mathrm{Kg})$

$\mathrm{X} 2=$ harga daging ayam kampung $(\mathrm{Rp} / \mathrm{Kg})$

$\mathrm{X} 3=$ harga daging sapi $(\mathrm{Rp} / \mathrm{Kg})$

$\mathrm{X} 6=$ harga minyak goreng $(\mathrm{Rp} /$ liter $)$

$\mathrm{X} 7=$ pendapatan $(\mathrm{Rp} /$ Bulan $)$

$\mathrm{X} 11=$ Pendidikan

$\mathrm{X} 12=$ Selera konsumen

Persamaan regresi cobb douglass diperoleh hasil bahwa jumlah permintaan akan broiler dipengaruhi oleh harga barang itu sendiri (daging broiler), harga daging ayam kampung, harga daging sapi, minyak goreng, pendapatan , pendidikan dan selera, namun masing-masing variabel memiliki pengaruh yang berbeda terhadap jumlah permintaan daging broiler di kota Malang.

\section{Kesimpulan}

Berdasarkan hasil penelitian yang dilaksanakan pada konsumen broiler di Kota Malang dapat disimpulkan bahwa bahwa faktor yang mempengaruhi tingkat permintaan daging broiler di kota Malang adalah harga barang itu sendiri (harga daging broiler), harga daging ayam kampung, harga daging sapi, harga minyak goreng, pendapatan per kapita, pendidikan dan selera konsumen.

\section{Daftar Pustaka}

Dinas Peternakan Provinsi Jawa Timur, 2016. Jumlah Produksi dan Populasi Ayam Pedaging. BPS Provinsi Jawa Timur. Surabaya.

Sadono, dan Sukirno. 2002. Pengantar Teori Mikroekonomi. Edisi Ketiga PT Raja Grafindo Persada. Jakarta.

Soekartawi .2002. Prinsip Dasar Ekonomi Pertanian. PT Raja GrafindoPersada. Jakarta.

Sugiyono. 2011. Metode Penelitian Administasi. Bandung : Alvabeta.

Roscoe 1975 dikutip dalam Sugiyono 2011, Metode Penelitian Bisnis, Salemba Empat, Jakarta. 